\title{
ANTIOXIDANT ASSAY OF PHASEOLUS VULGARIS L BEANS ETHANOLIC EXTRACT IN VITRO AND IN VIVO
}

\section{DWI RITA ANGGRAINI ${ }^{1 *}$, TRI WIDYAWATI ${ }^{2}$, MUTIARA INDAH SARI ${ }^{3}$, HENNY SRI WAHYUNI ${ }^{4}$, SITI SYARIFAH ${ }^{1}$, ADE PUTRA FRATAMASINAGA ${ }^{5}$, MAYA ANJELIR ANTIKA ${ }^{5}$}

${ }^{1}$ Department of Anatomy, Faculty of Medicine, Universitas Sumatera Utara, Jalan dr. Mansur, USU-Kampus, Medan 20155, Indonesia. ${ }^{2}$ Department of Pharmacology and Therapeutic, Faculty of Medicine, Universitas Sumatera Utara, Jalan dr. Mansur, USU-Kampus, Medan 20155, Indonesia. ${ }^{3}$ Department of Biochemistry, Faculty of Medicine, Universitas Sumatera Utara, Jalan dr. Mansur, USU-Kampus, Medan 20155, Indonesia. ${ }^{4}$ Department of Pharmaceutical Chemistry, Faculty of Pharmacy, Universitas Sumatera Utara, Jalan Almamater, USUKampus, Medan 20155, Indonesia. ${ }^{5}$ Department of Biomedical Science, Faculty of Medicine, Universitas Sumatera Utara, Jalan dr. Mansur, USU-Kampus, Medan 20155, Indonesia. Email: dwirita@usu.ac.id

Received: 22 October 2018, Revised and Accepted: 05 April 2018

ABSTRACT

Objectives: Antioxidant is a substance such as Vitamin C that able to remove potentially damaging oxidizing agents. Malondialdehyde (MDA) is an important marker of oxidative stress that have correlation with Type 2 diabetes mellitus (DM) progression. Phaseolus vulgaris L (PV) (beans) is one of the alternative medicines to treat DM in Indonesia. We investigated the antioxidant activity of ethanolic extract on PV (EEPV) beans using in vitro and in vivo model.

Methods: Antioxidant assay in vitro was conducted using 1,1-diphenyl-2-picrylhydrazyl (DPPH) method. Alloxan (120 mg/kg, intraperitoneally)induced diabetic rats were divided into 5 groups (n=5), i.e., NC: Normal control, P1: Diabetic-control, P2, P3, and P4 (200 mg/kg, 400 mg/kg, and $600 \mathrm{mg} / \mathrm{kg}$ of EEPV, orally) for 28 days. MDA serum level was evaluated using spectrophotometer. The data were analyzed by one-way ANOVA test.

Results: The antioxidant assay in vitro showed that EEPV has very weak (IC50=641.87 $\mu \mathrm{g} / \mathrm{ml}$, whereas Vitamin C as standard showed very strong activity (IC50=2.95 $\mu \mathrm{g} / \mathrm{ml}$ ). MDA level were $2.80 \pm 0.09 \mathrm{nmol} / \mathrm{ml}(\mathrm{NC}), 3.30 \pm 0.42 \mathrm{nmol} / \mathrm{ml}(\mathrm{P} 1), 3.27 \pm 4.23 \mathrm{nmol} / \mathrm{ml}(\mathrm{P} 2), 2.93 \pm 0.05 \mathrm{nmol} / \mathrm{ml}(\mathrm{P} 3)$, and $3.17 \pm 0.25 \mathrm{nmol} / \mathrm{ml}(\mathrm{P} 4)$. There was no significant differences among normal control, diabetic-control, and EEPV-treated groups ( $>0.05$ ).

Conclusion: EEPV showed a very weak antioxidant activity in vitro.

Keywords: Antioxidant, Phaseoleus vulgaris L, Beans, Ethanolic extract, In vitro, In vivo.

(C) 2018 The Authors. Published by Innovare Academic Sciences Pvt Ltd. This is an open access article under the CC BY license (http://creativecommons. org/licenses/by/4. 0/) DOI: http://dx.doi.org/10.22159/ajpcr.2018.v11s1.26584

\section{INTRODUCTION}

Free radicals, highly reactive, able to damage molecules, are known increasingly as an underlying mechanism of cells injury that affecting human health and disease, associated with diabetes mellitus (DM) Type 2 [1].

In diabetes, impaired glucose metabolism may lead to an increase in hydroxyl radical production. Free radicals may also be formed through the autoxidation of unsaturated lipids in plasma and membrane lipids. The free radicals product may react with polyunsaturated fatty acids in cell membranes leading to lipid peroxidation [2]. Thus, it will damage the membrane lipid bilayer structure that causes membrane-bound receptors and enzymes inactivation, so that the tissue permeability is increased. The end products of lipid peroxidation are propanal, hexanal,4-hydroxynonenal, and malondialdehyde (MDA) [3]. MDA is a highly mutagenic compound that represents the activity of free radicals in the cells so can be used as a biomarker of the lipid peroxidation [4-6].

Beans (Phaseolus vulgaris L. [PV]) are grain legumes, commonly used as cuisine, that have been consumed among people worldwide [7]. Conventionally, people were also use it as a herb to get its weight loss activity, antidiabetes, and antioxidant [8]

The previous study showed that oral administration of aqueous extract of PV (AEPV) ( $200 \mathrm{mg} / \mathrm{kg}$ body weight [BW]) for 45 days to diabetic rats significantly decreased the plasma thiobarbituric acid (TBA)-reactive substances and hydroperoxides. AEPV at $400 \mathrm{mg} / \mathrm{kg}$ BW was also significantly reduce $(\mathrm{p}<0.05)$ the values of alanine aminotransferase, aspartate aminotransferase, and alkaline phosphatase [8].
Many studies have shown that oxidative stress/free radical is strongly associated with diabetes and particularly with the complications of diabetes [9]. Our previous study showed the antihyperglycemic activity of ethanolic extract on PV (EEPV). Therefore, the current study was conducted to evaluate its antioxidant activity.

\section{METHODS}

\section{Chemical and reagents}

Alloxan, formalin buffer 10\%, heparin sodium, sodium chloride, cell lysis buffer, paraffin wax, TBA reagent, aquabidest, $70 \%$ and $80 \%$ aqueous alcohol and 96\% absolute alcohol, xylitol, glycerin, Mayer's hematoxylin, eosin, Canada balsam. All other chemicals were of analytic grade.

\section{Animals}

Male healthy Wistar rats (Rattus norvegicus) were obtained from animal house of Universitas Sumatera Utara. The rats with following inclusion criteria were included in the study, i.e., age 2-3 months, 150-200 g BW. The study was conducted after approved by Animal Research Ethics Committees, Faculty of Mathematics and Natural Sciences (FMIPA), and Universitas Sumatera Utara (No. EC: 115/KEPH-FMIPA/2017).

\section{Plant material and preparation of EEPV}

The PV beans (Fig. 1) were collected at the Berastagi city, on of district in Medan (Sumatera Utara) (Fig. 2), in February 2017 and was authenticated by the Department of Botany, Universitas Sumatra Utrara. EEPV was done with maceration method that used ethanol solvent with ratio $1: 10(\mathrm{w} / \mathrm{v})$. The dried $\mathrm{PV}$ was dissolved by 10 parts after that poured with 75 parts of ethanol $96 \%$ as the essence. Closed and left 
for 5 days and shielded from the light while stirring occasionally. After 5 days, the solution was filtered, the pulp was squeezed, and washed with enough liquid essence to obtain 100 parts. The extract was obtained evaporated at a temperature of $50^{\circ} \mathrm{C}$

\section{Induction of diabetes}

Alloxan solution in $0.1 \mathrm{M}$ citric buffer was administered at single dose of $120 \mathrm{mg} / \mathrm{kg}$ BW intraperitoneally. Diabetes was confirmed by determining the blood glucose concentration using glucometer ( ${ }^{\circledR}$ glucoDrTM model AGM-2100), after $72 \mathrm{~h}$ of alloxan injection. The rats with blood glucose level $>250 \mathrm{mg} / \mathrm{dl}$ were selected for the study $[10,11]$.

\section{Experimental design}

The animals were divided randomly into five groups of five rats each and treated as follows:

1. Group I (NC): Normal control rats (standard pellets and water adlibitum) for 28 days.

2. Group II (P1): Diabetic control rats were administered with $120 \mathrm{mg} / \mathrm{kg}$ of alloxan, standard pellets, and water ad libitum for 28 days.

3. Group III (P2): Diabetic rats+EEPV at dose of $200 \mathrm{mg} / \mathrm{kg} \mathrm{BW} /$ day for 28 days.

4. Group IV (P3): Diabetic rats+EEPV at dose of $400 \mathrm{mg} / \mathrm{kg} \mathrm{BW} /$ day for 28 days.

5. Group V (P4): Diabetic rats+EEPV at dose of $600 \mathrm{mg} / \mathrm{kg} \mathrm{BW} /$ day for 28 days.
Antioxidant assay: 1,1 Diphenyl-2-picrylhydrazyl (DPPH) radical scavenging assay

The DPPH radical-scavenging activities of experimental autoimmune encephalomyelitis were determined according to Molyneux [12]

\section{DPPH preparation}

$20 \mathrm{mg}$ of DPPH was dissolved in methanol until $50 \mathrm{ml}$ to obtain $400 \mathrm{mcg} / \mathrm{ml}$ of DPPH solution.

\section{Determination of maximum wavelength}

As much as $5 \mathrm{ml}$ of DPPH solution was put in a $50 \mathrm{ml}$ of mixed flask, and the volume was adjusted with methanol to the mark line, to obtain a solution with a concentration of $40 \mathrm{mcg} / \mathrm{ml}$. The absorbance was measured at 400-800 $\mathrm{nm}$ wavelength. The spectrum obtained then was observed.

\section{Measurement of DPPH absorbance after addition of EEPV}

As much as EEPV $100 \mathrm{mg}$ was dissolved in $50 \mathrm{ml}$ of methanol to obtain $2000 \mu \mathrm{g} / \mathrm{ml}$ (LIB). Different sample volumes of LIB $(10,12.5,15,17.5$, $20 \mathrm{ml}$ ) were put in mixed flask $(50 \mathrm{ml})+5 \mathrm{ml}$ DPPH $(400 \mu \mathrm{g} / \mathrm{ml})$ to obtain different extract concentration, i.e., 400, 500, 600, 700, 800, and DPPH $40 \mathrm{mcg} / \mathrm{ml}$. After 10-30 min, the absorbance was measured at maximum wavelength $516.5 \mathrm{~nm}$.

\section{Measurement of DPPH absorbance after addition of Vitamin C}

Vitamin $\mathrm{C}$ as much as $25 \mathrm{mg}$ crystal was dissolved in methanol until $100 \mathrm{ml}$, to obtain $250 \mu \mathrm{g} / \mathrm{ml}$ (LIB). Different volume of LIB $(0.2,0.4,0.6$, $0.8,1 \mathrm{ml})$ were put $50 \mathrm{ml}$ mixed flask of each. $5 \mathrm{ml} \mathrm{DPPH}(400 \mu \mathrm{g} / \mathrm{ml})$ was added to obtain different Vitamin C concentrations, i.e., 1, 2, 3, 4, 5 , and DPPH $40 \mu \mathrm{g} / \mathrm{ml}$ ). The absorbance was measured at wavelength $516.5 \mathrm{~nm}$ after $10-30 \mathrm{~min}$.

The assay was performed in triplicate. The percentage of DPPH radical scavenging activity was calculated as follows

$$
\text { DPPH radical scavenging activity }(\%)=\frac{\mathrm{ADPPH}-\mathrm{A} \text { sample }}{\mathrm{A} \mathrm{DPPH}} \times 100
$$

A DPPH = Absorbance of DPPH without sample A sample $=$ Absorbance of DPPH with sample $\mathrm{IC}_{50}$ was determined using regression linear equation.

\section{Measurement of MDA level}

MDA level from the blood sample is determined by TBA method that measured using spectrophotometer at wavelength $532 \mathrm{~nm}$. The presence of MDA is identified by the pink color formation after it reacted with TBA in acidic conditions. Measurement of MDA conducted at the Laboratory of Biochemistry Faculty of Medicine, Universitas Sumatera Utara. Data were analyzed using one-way ANOVA, $\mathrm{p}<0.05$ considered as statistically significant.

\section{RESULTS}

DPPH radical scavenging assay

Tables 1-3 show the activity of EEPV and Vitamin C as radical scavengers.

The antioxidant assay in vitro showed that EEPV has very weak (IC50 $=641.87 \mu \mathrm{g} / \mathrm{ml}$, whereas Vitamin $\mathrm{C}$ as standard showed very strong activity (IC50 $=2.95 \mu \mathrm{g} / \mathrm{ml}$ ).

MDA level

MDA level of this study is shown in Table 4

There was no significant differences among normal-control, diabeticcontrol, and EEPV-treated groups ( $\mathrm{p}>0.05$ ).

\section{DISCUSSION}

Diabetes can be produced in animals by alloxan induced, result in the production of active oxygen species from an imbalance between radical-generating and radical-scavenging systems, i.e., increased free

Fig. 2: Location of Berastagi 
radical production or reduced activity of antioxidant defenses or both. Several studies have shown that DM (Types 1 and 2) is accompanied by the increased formation of free radicals and decreased antioxidant capacity, leading to oxidative damage of cell components [13]. Scavengers of free radicals are effective in preventing diabetes in these animal models.

PV has a notable place in the folklore throughout the world and in the traditional usage of many cultures such as antidiabetic $[14,15]$. In Indonesia, this plant commonly grows in Karo lands, especially Berastagi, one of the districts in North Sumatera, Indonesia. Local residents also often use it to alleviate the rise of blood glucose levels.

The present study continued with antioxidant activity test using DPPH radical-scavenging method. This assay was used to evaluate the strength of antioxidant properties of EEPV compare to Vitamin C. Vitamin C, is a water-soluble free radical scavenger that can change to the ascorbate radical by donating an electron to the lipid radical to terminate the lipid peroxidation chain reaction [16]. The roles of many dietary polyphenolic constituents derived from plants are more effective antioxidants in vitro than Vitamins $\mathrm{E}$ or $\mathrm{C}$, and thus might contribute significantly to the protective effects [17]. The more polar ones (ethyl acetate and n-butanol) are those that generally have higher antioxidant activity [18].

Table 1: DPPH radical scavenging activity of EEPV

\begin{tabular}{lll}
\hline EEPV $(\boldsymbol{\mu g} / \mathbf{m l})$ & Absorbance & $\begin{array}{l}\text { DPPH radical scavenging } \\
\text { activity }(\%)\end{array}$ \\
\hline 0 & 0.8080 & 0 \\
400 & 0.5893 & 27.0627 \\
500 & 0.5053 & 37.4587 \\
600 & 0.4227 & 47.6898 \\
700 & 0.3777 & 53.2591 \\
800 & 0.2780 & 65.5940 \\
\hline
\end{tabular}

DPPH: 1,1-Diphenyl-2-picrylhydrazyl, EEPV: Ethanolic extract on Phaseolus vulgaris $\mathrm{L}$

Table 2: DPPH radical scavenging activity of Vitamin C

\begin{tabular}{lll}
\hline Vitamin C $(\boldsymbol{\mu g} / \mathbf{m l})$ & Absorbance & $\begin{array}{l}\text { DPPH radical scavenging } \\
\text { activity }(\%)\end{array}$ \\
\hline 0 & 0.8497 & 0 \\
1 & 0.7407 & 12.8286 \\
2 & 0.5773 & 32.0518 \\
3 & 0.4350 & 48.8034 \\
4 & 0.2650 & 68.8113 \\
5 & 0.0953 & 88.7799 \\
\hline
\end{tabular}

DPPH: 1,1-Diphenyl-2-picrylhydrazyl

Table 3: $\mathrm{IC}_{50}$ of EEPV and Vitamin C on DPPH free radical

\begin{tabular}{ll}
\hline Sample & IC $_{50}(\mathbf{m c g} / \mathbf{m l})$ \\
\hline EEPV & 641.87 \\
Vitamin C & 2.95 \\
\hline
\end{tabular}

DPPH: 1,1-Diphenyl-2-picrylhydrazyl, EEPV: Ethanolic extract on Phaseolus vulgaris $\mathrm{L}$

Table 4: The MDA level of rats on day 28

\begin{tabular}{lll}
\hline Group & MDA $(\mathbf{n m o l} / \mathbf{m l})$ & $\mathbf{p}$ \\
\hline K & $2.80 \pm 0.09$ & 0.147 \\
P1 & $3.30 \pm 0.42$ & \\
P2 & $3.27 \pm 4.23$ & \\
P3 & $2.93 \pm 0.05$ & \\
P4 & $3.17 \pm 0.25$ &
\end{tabular}

Tables 1-3 show the activity of EEPV and Vitamin C as radical scavengers. The higher of EEPV lowered the absorbance which means the scavenging activity of EEPV increased following the higher concentration of EEPV. The IC50 values showed the inhibition concentration of DPPH at 50\%. The results showed that IC50 of EEPV was $641.87 \mu \mathrm{g} / \mathrm{ml}$ whereas Vitamin C as standard was at $2.79 \mu \mathrm{g} / \mathrm{ml}$. A compound claimed to have antioxidant activity when the IC50 as the following categories: $<50 \mu \mathrm{g} / \mathrm{ml}$ (very strong), $50-100 \mu \mathrm{g} / \mathrm{ml}$ (strong), $101-150 \mu \mathrm{g} / \mathrm{ml}$ (moderate), and 151-200 $\mu \mathrm{g} / \mathrm{ml}$ (weak). Therefore, the present study concluded that EEPV has very weak antioxidant properties while Vitamin C showed a very strong antioxidant activity.

In the present study, the increased levels of MDA clearly show that diabetic group (P1) was exposed to an increased oxidative stress through lipid peroxidation [19]. Decreased levels of MDA showed in P3 (EEPV at dose of $400 \mathrm{mg} / \mathrm{kg} \mathrm{BW}$ ).

The reports about the status of antioxidants and antioxidant enzymes in diabetic patients are very contradictory, both increase and decrease of antioxidantactivity have been reported [19]. Products of membrane lipid peroxidation and other oxidants like $\mathrm{H} 2 \mathrm{O} 2$ may react with superoxide dismutase resulting in oxidative modification thereby causing loss of enzyme activity [20]. Furthermore, diabetic hyperglycemia leads to glycation and inactivation of superoxide dismutase thus attributing to its decrease.

\section{CONCLUSION}

EEPV showed a very weak antioxidant activity in vitro.

\section{ACKNOWLEDGMENT}

The authors gratefully acknowledge to the Universitas Sumatera Utara for supporting this study.

\section{CONFLICTS OF INTERESTS}

The author declares no conflicts of interest.

\section{REFERENCES}

1. Johansen JS, Harris AK, Rychly DJ, Ergul A. Oxidative stress and the use of antioxidants in diabetes: Linking basic science to clinical practice. Cardiovasc Diabetol 2005;4:5

2. Baynes JW. Role of oxidative stress in development of complications in diabetes. Diabetes 1991;40:405-12.

3. Young WK, Tatiana VB. Oxidative stress in angiogenesis and vacular disease. Blood 2014;123:5

4. Yoshikawa T, Naito Y. What is oxidative stress? J Japan Med Assoc 2002;45:217-76.

5. Antonio A, Mario FM, Sandro A. Lipid peroxidation: Production metabolism and signalling mechanism of malonaldehyde and 4-Hydroxy-2-Nonenal. Xidative Med Cell Longev 2014. Article ID: 360438, 31 Pages.

6. Sitorus MS, Anggraini DR, Hidayat. Decreasing free radicals level on high risk person after vitamin $\mathrm{C}$ and $\mathrm{E}$ supplement treatment. In IOP conference series. Mater Sci Eng 2017;180:12093.

7. Broughton WJ, Herna'ndez G, Blair M, Beebe S, Gepts P, Vanderleyden J. Beans (Phaseolus spp.)-model food legumes. Plant Soil 2003;252:55-128.

8. Venkateswaran S, Pari L. Antioxidant effect of Phaseolus vulgaris in streptozotocin-induced diabetic rats. Asia Pac J Clin Nutr 2002;11:206-9.

9. Golbidi S, AlirezaEbadi S, Laher I. Antioxidants in the treatment of diabetes. Curr Diabetes Rev 2011;7:106-25.

10. Chougale AD, Panaskar SN, Gurao PM, Arvindeka AU. Optimization of Alloxan dose is Essential to Induce Stable Diabetes for Prolong Period; 2007. Available from: http://www.sciarlet.net/ fulltext/?doi=ajb2007.402.408.

11. Nugroho AE. Animal models of diabetes mellitus: Pathology and mechanism of some diabetogenics. Biodivers J Biol Divers 2006;7:378-82.

12. Molyneux P. The use of the stable free radical diphenylpicrylhydrazyl (DPPH) for estimating antioxidant activity. Songklanakarin J Sci Technol 2004;26:211-9.

13. Bashan N, Kovsan J, Kachko I, Ovadia H, Rudich A. Positive and negative regulation of insulin signaling by reactive oxygen and nitrogen 
species. Physiol Rev 2009;89:27-71.

14. Carai MA, Fantini N, Loi B, Colombo G, Riva A, Morazzoni P. Potential efficacy of preparations derived from Phaseolus vulgaris in the control of appetite, energy intake, and carbohydrate metabolism. Targ Therap 2009;2:149-53.

15. Mishra SB, Rao CV, Ojha SK, Vijayakumar M, Verma A. An analytical review of plants for anti-diabetic activity with their phytoconstituent and mechanism of action: A review. Int J Pharm Sci Res 2010;1:29-44.

16. Nimse SB, Pal D. Free radicals, natural antioxidants, and their reaction mechanisms. Rsc Adv 2015;5:27986-8006.

17. Rice-Evans C, Miller N, Paganga G. Antioxidant properties of phenolic compounds. Trends Plant Sci 1997;2:152-9.
18. Mensor LL, Menezes FS, Leitão GG, Reis AS, dos Santos TC, Coube CS, et al. Screening of Brazilian plant extracts for antioxidant activity by the use of DPPH free radical method. Phytother Res 2001;15:127-30.

19. Mahboob M, Rahman MF, Grover P. Serum lipidperoxidation and antioxidant enzyme levels in maleand female diabetic patients. Singapore Med J 2005;46:322-4.

20. Kumawat M, Singh I, Singh N, Singh V, Kharb S. Lipid peroxidation and lipid profilein Type II diabetes mellitus. WebmedCentral Biochem 201;3:WMC003147.

21. Laight DW, Carrier MJ, Anggård EE. Antioxidants, diabetes and endothelial dysfunction. Cardiovasc Res 2000;47:457-64. 